\title{
Landslide and rockfall analysis of the western part of the Pavlov Hills in southern Moravia
}

\author{
Filip Opálka
}

\begin{abstract}
Masaryk University, Faculty of Science, Department of Geological Sciences; Kotlářská 267/2, 61137 Brno, Czech Republic; e-mail: FilipOpalka@seznam.cz
\end{abstract}

(C) 2015 Authors. This is an open access publication, which can be used, distributed and reproduced in any medium according to the Creative Commons CC-BY 4.0 License requiring that the original work has been properly cited.

My presentation is focused on the analysis and mapping of landslides and rock falls from the western part of the Pavlov Hills in southern Moravia. The Pavlov Hills are situated in the NW margin of the outer units of the Carpathian Flysh belt and are formed by Jurassic to Cretaceous flysh sediments incorporated into nape sheets of Carpathian Flysh Belt (Ždánice and Pouzdřany Units) (Poul 2006). Landslides are important elements in evolution of landforms and represent a serious geohazard in many areas of the world. Different kinds and types of landslides cause problems and difficulties to human society every year and that is why they are one of human treating natural disasters.

There are only a few areas with recorded risks of landslides in the Czech Republic. One of these areas is the area of the Pavlov Hills. There is not enough of sufficient attention payed to geological mapping of the area of Pavlov Hills, because there are not many human settlements or infrastructure nearby. My field work involved observation and measurement of faults, rockfalls and slides.
My presentation is focused on updating existing maps of slope instabilities in the mentioned area. For that reason, previously mapped areas were documented, registered and included into a map sheet. Eleven sliding localities in the Pavlov Hills were described and documented.

Into the final map I included the additions according to type: flow slides -5 , planar slides -4 , and 2 rock falls. The resulting map with accompanying sheets can be used as a basis for further mapping or other activities associated with the observation of landslides such as landslide prevention and remediation, clarification of the hydrogeological conditions of the area and verification of geological slip surfaces, which are not affected by landslides.

\section{REFERENCES}

Poul I., 2006. Nový tektonický model Pavlovských vrchư: flat-ramp-flat geometrie v externích Západnich Karpatech. Př́rodovědecká fakulta Masarykovy Univerzity, Brno [MSc thesis]. 